\title{
Detrimental effects of volcanic ash deposition on bee fauna and plant-pollinator interactions
}

\author{
Carolina L. Morales ${ }^{1, \otimes}$; Agustín Saez ${ }^{1}$; Marina P. Arbetman ${ }^{1,2}$; Laura Cavallero ${ }^{1} \&$ \\ Marcelo A. Aizen ${ }^{1}$ \\ 1. Laboratorio Ecotono, INIBIOMA, Universidad Nacional del Comahue - CONICET, Bariloche, Argentina. 2. Universidad \\ Nacional de Rio Negro. Sede Andina, Bariloche, Argentina
}

\begin{abstract}
Aвstract. Volcanic eruptions are large-scale natural disturbances, which can negatively affect insect fauna and the ecological interactions in which they are involved. The 2011 eruption of the volcanic complex Puyehue Cordón-Caulle (PCC) produced the deposition of 950 million tons of ash on Argentine Patagonia, creating an ash layer of varying thickness. Although experimental studies confirmed that PCC volcanic ash negatively affects survival and behavior in many insect taxa, including bees, the effects of ash deposition on the plant-pollinator interactions (PPI) of this group of insects in natural landscapes remained untested. We evaluated the effect of the gradient of increasing ash layer thickness $(0-15 \mathrm{~cm})$ on: (1) number of wild bees visiting flowers and total bee richness in 16 raspberry fields after the eruption, (2) number of native (Bombus dahlbomii) and invasive (B. terrestris and B. ruderatus) bumble bees foraging on wild flowers in 10 sites before and after the eruption, and (3) the proportion of "triggered" flowers (i.e. papilionaceous flowers visited for first time by large bees) in 32 populations of the invasive shrub scotch broom (Cytisus scoparius), before and after the eruption. With the increase of ash deposition, we found a consistent and significant decrease in (1) the number of wild bees and total bee richness visiting raspberry flowers; (2) the number of bumble bees, particularly B. terrestris, visiting wild flowers; and (3) the proportion of triggered flowers of scotch broom. Thus, volcanic eruptions can exert a detrimental effect on bee fauna and concomitant PPI, with a potential cascade effect on the pollination service to crops, the spread of invasive bumble bees, and the pollination success of invasive plants.
\end{abstract}

[Keywords: Bombus terrestris, bumble bees, large scale disturbance, pollination, Puyehue Cordón-Caulle Volcano, raspberry, scotch broom]

Resumen: Efectos perjudiciales de la deposición de ceniza volcánica en abejas y en las interacciones planta-polinizador: Las erupciones volcánicas son perturbaciones naturales a gran escala, que pueden afectar negativamente a la fauna de insectos y las interacciones ecológicas en las que están involucrados. La erupción del complejo volcánico Puyehue Cordón-Caulle (PCC) en el 2011 depositó 950 millones de toneladas de cenizas en la Patagonia Argentina, creando una capa de cenizas de espesor variable. Si bien los estudios experimentales confirmaron que las cenizas del PCC afectan negativamente la supervivencia y el comportamiento en varios taxones de insectos, incluidas las abejas, el efecto de la deposición de ceniza en las interacciones planta-polinizador (IPP) asociadas a éstas últimas no ha sido investigado en paisajes naturales. Evaluamos el efecto del gradiente de creciente grosor de la capa de cenizas $(0-15 \mathrm{~cm}$.) en: (1) el número de abejas silvestres visitando flores de frambuesa y riqueza total de abejas en 16 campos, (2) el número de abejorros nativos (Bombus dahlbomii) e invasores (B. terrestris y B. ruderatus) forrajeando en flores silvestres en 10 sitios, y (3) la proporción de las flores "disparadas" (flores papilionáceas visitadas por primera vez por abejas de gran tamaño) en 32 poblaciones del arbusto invasor Cytisus scoparius (retama). Con el aumento en el espesor de la capa de ceniza, encontramos una fuerte y consistente disminución de: (1) el número de abejas silvestres y la riqueza de abejas totales en flores de frambuesa; (2) el número de abejorros, en particular de B. terrestris, visitando flores silvestres; $\mathrm{y}$ (3) la proporción de flores de retama disparadas. Las erupciones volcánicas pueden afectar fuertemente a la fauna de abejas y las interacciones planta-polinizador, con posibles efectos en cascada sobre el servicio de polinización de cultivos, la expansión de abejorros invasores y el éxito de polinización de una planta invasora.

[Palabras clave: abejorros, Bombus terrestris, disturbios de gran escala, frambuesa, polinización, retama, Volcán Puyehue Cordón-Caulle]

\section{INTRODUCTION}

Volcanic eruptions can be very intense and highly sporadic natural disturbances, sometimes with multiple, complex and longlasting consequences (Wilson et al. 2010; Schowalter 2012). In addition to the direct

Editor invitado: Thomas Kitzberger

$\triangle$ moralesc@comahue-conicet.gob.ar and more local short-term effects of the volcano blast and lava flow, the thin portion of airborne material (commonly known as ash) released by volcanic eruptions can reach remote locations and persist over long periods of time, affecting flora and fauna even after the Última versión: 1 de febrero de 2014; Aceptado: 18 de febrero. 
end of the volcanic activity (Wilson et al. 2010). The magnitude of the disturbance is expected to decrease with distance to the epicenter, which offers the opportunity to evaluate its biotic consequences by conducting surveys along such disturbance gradients.

Depending on ash characteristics (i.e. amount, particle size, physical and chemical components) volcanic events impose different intensities of stress on organisms and the ecological processes in which they are involved. In particular, changes in insect survival and behavior after volcanic eruptions have been previously recorded (Marske et al. 2007; Woyke \& Gabka 2011). Mechanisms underlying decreased survival are mostly related to the hygroscopic and abrasive nature of volcanic particles, which alters tissues and vital systems (Klostermeyer et al. 1981) and processes such as respiration and digestion (Wille \& Fuentes 1975).

Nectivorous insects, such as bees, are expected to be especially susceptible to the ingestion of ash-contaminated resources (Gullan \& Cranston 2005), as well as to the abrasive effect of ash because they lack protective mechanisms against abrasion, typical of soil-feeding insects. Ash in the atmosphere can also alter bee flight patterns (Woyke \& Gabka 2011), which may eventually affect their foraging performance. Despite the importance of pollinators in natural and agricultural landscapes, only few studies have reported effects of volcanic ash on bees (however, see Martínez et al. 2012). Decreases in bee abundance or changes in their behavior may generate profound changes in plantpollinator interactions and consequently in plant reproduction success, with knock-on consequences at ecosystem level.

The Andes mountain range, which stretches along the western edge of South America from Venezuela to Tierra del Fuego, is a region of high volcanic activity. On June $4^{\text {th }} 2011$ the volcanic complex Puyehue Cordón-Caulle (PCC; $2236 \mathrm{~m}, 40^{\circ} 02^{\prime} 24^{\prime \prime} \mathrm{S} ; 70^{\circ} 14^{\prime} 26^{\prime \prime} \mathrm{W}$ ) in Chile, but just a few kilometers away from the Argentine border, experienced a major eruption event (GOES, 2011) after 51 years of inactivity (Singer et al. 2008). Four months later, 950 million tons of ash had rained down on Argentine territory (Gaitán et al. 2011a). The amount of ash deposited varied with distance from the volcano and the direction of the dominant winds created a geographic gradient in the ash layer thickness (Gaitán et al. 2011a). Río Negro and Neuquén were the Argentine provinces most severely affected, with ash covering ca. 19.7 million and 4.7 million hectares, respectively (Gaitán et al. 2011a). The ash layer persisted almost unaltered on the eastern slopes of the Andes, although it was slightly compacted by the effect of precipitation and vegetation, six months after the onset of the activity (Gaitán et al. 2011b).

Ash from the PCC is predominantly composed of glass shards $\left(\mathrm{SiO}_{2}\right)$ and alumina $\left(\mathrm{Al}_{2} \mathrm{O}_{3}\right)$ (Buteler et al. 2011; Mogni et al. 2011), two extremely abrasive substances well-known for their insecticidal properties (Fernandez-Arhex et al. 2013). This volcanic ash can erode insect cuticles, block the spiracles, and have a general desiccating effect on many invertebrates (Buteler et al. 2011; Fernandez-Arhex et al. 2013). Although there is agreement on the insecticidal effect of volcanic ash in general, and of those delivered by the PCC 2011 eruption in particular, most studies focused on folivorous, predatory, omnivorous or parasitoid taxa (e.g., Hymenoptera: Vespidae, Formicidae; Coleoptera: Curculionidae, Silvanidae, Tenebrionidae), while effects on nectar and pollen feeding insects, particularly bees (Hymenoptera, Superfamily Apoidea) are practically unknown. Martínez et al. (2012) showed that ingestion of sugar solution and water experimentally contaminated with ash reduced honey bee survival. They also showed that honey bee visitation to lavender flowers dropped notably during the first two hours after they were experimentally dusted with ash from the PCC 2011 eruption; however, visitation rates partially recovered 24 hours following ash dusting.

Despite experimental studies showing altered survival and flower visitation of bees after ash exposure; to our knowledge no study has previously evaluated net effects of ash deposition on bee fauna and their consequences on plant-pollinator interactions in real-world landscapes. Here, we evaluated the effect of ash deposition on (a) the number of wild bees visiting flowers and total bee richness in raspberry fields, (b) the number of bumble bees foraging on wild flower patches, and (c) the proportion of triggered flowers (i.e. first visit to papilonaceous flowers by large bees) of scotch broom (Cytisus scoparius). 


\section{MATERIAL AND METHODS}

\section{Study area and species}

The studies were conducted in the northern Patagonian Andean region of Argentina ( 39 - 41 ${ }^{\circ}$ $\mathrm{S}$, Figure 1). Soils are mostly derived from volcanic ash (andisoils). Due to the rainshadow effect of the Andes on the westerlies, mean annual precipitation decreases from $>3000 \mathrm{~mm}$ at the Chile-Argentina border to $<800 \mathrm{~mm}$ only $50 \mathrm{~km}$ eastward. Approximately $60 \%$ of the annual precipitation falls in the late autumn and winter seasons (from May to August).

Rubus ideaus (raspberry) is a shrub cultivated for its fruit (Crane \& Walker 1984). Each of the multi-pistillated raspberry flowers can develop into a drupelet if properly pollinated, producing an aggregate fruit known as "polidrupe". To ensure production of commercial-quality fruit, most if not the entire flower ovules have to be fertilized (Cane 2005). Despite self-compatibility, the design of the raspberry flower precludes completely autonomous self-pollination (Cane 2005). Thus, fruit production decreases by approximately $10-40 \%$ in the absence of pollinators (Klein et al. 2007; Morales 2009).

Bombus dahlbomii (Guérin-Meneville) is the only native bumble bee inhabiting the temperate forests of the Patagonian Region in southern Argentina and Chile, where it used to be the main pollinator of many plant species (Aizen et al. 2002; Vázquez \& Simberloff 2003). This region has been sequentially invaded by the European species $B$. ruderatus and B. terrestris (Roig-Alsina \& Aizen 1996; Torretta et al. 2006), following their introduction to Chile for crop pollination. Currently, the three species coexist in the northern Patagonian Andean region of Argentina, the area most influenced by the PCC eruption (Figure 1). However, B. terrestris is by far the most abundant species whereas $B$. dahlbomii is almost ecologically extinct (Morales et al. 2013).

Cytisus scoparius (L.) Link (scotch broom), a shrub native to Europe, has become a vigorous invader of many temperate regions of the world (Caldwell 2006; Potter et al. 2009) including the northern Patagonian Andean region of Argentina (Pérez 2008). This species is self-incompatible, and completely dependent on large bees for pollination due to the structure of its papilionaceus flowers (Parker 1997). A foraging bee must be large enough to push the keel down and split the petals, thus exposing the fertile parts and releasing pollen from the anthers, behavior known as "triggering". Once a flower has been triggered, it does not return to the previous morphology, and is thus easily recognized in the field, as the fertile parts are exposed. Therefore, the proportion of triggered flowers provides an estimation of the visitation rate of large bees, which in this region are mainly bumble bees. Furthermore, because of severe pollination limitation in this species, the proportion of triggered flowers is also a good indicator of reproductive success (Parker 1997).

\section{Sampling procedure}

In January-early February 2012, during the austral summer, i.e. 7-8 months after the major PCC volcanic eruption and ash release, we surveyed bees visiting 16 raspberry fields, which were located across a gradient of ash layer thickness ranging from 0 to ca. $10 \mathrm{~cm}$ (Figure 1). Minimum distance between sampled fields was $>1 \mathrm{~km}$, exceeding the expected mean foraging distance of most foraging bees (Gathmann \& Tscharntke 2002; Steffan-Dewenter \& Kuhn 2003; Klein et al 2004; Greenleaf et al. 2007). Thus, each field can be considered as an independent replicate regarding its bee-visiting fauna. In each field, we recorded the number and identity of bees visiting 5-10 focal flowers during $5 \mathrm{~min}$. We conducted 20 pollinator-

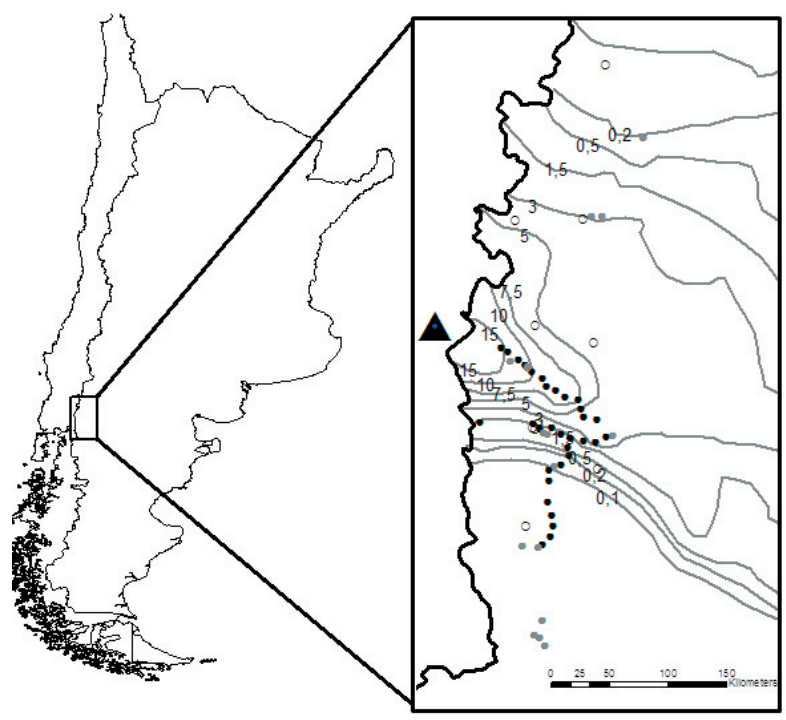

Figure 1. Overview map of Argentina, with a detail of the study area, showing the location of the Puyehue Cordon-Caulle (PCC) volcanic complex (Large triangle) in neighboring Chile, the raspberry fields (grey circles), the bumble bee transects (white circles), and the scotch broom populations (black circles). Numbers on the isolines indicate ash layer thickness $(\mathrm{cm})$.

Figura 1. Mapa de Argentina, con un detalle del área de estudio, mostrando la ubicación del complejo volcánico Puyehue Cordón-Caulle (PCC) (triángulo grande) en el vecino pais de Chile, los campos de frambuesa (círculos grises), las transectas de abejorros (círculos blancos), y las poblaciones de retama (círculos negros). Los números en las isolíneas indican el espesor de la capa de cenizas. 
observation intervals per field, from 10:00 to 18: 00. More details on this sampling in Saez et al. (submitted).

In January-February 2011 and 2012 (i.e., 4-5 months before and 7-8 months after the eruption, respectively), we surveyed bumble bees (namely, the native Bombus dahlbomii, and the invaders $B$. terrestris and B. ruderatus) foraging on patches of wild flowers in 10 sites scattered across a gradient of ash layer thickness ranging from 0 to $5 \mathrm{~cm}$ (Figure 1 ). At each site, we counted the number of individuals of each species that were foraging on flower patches during a 30 min.- interval walking along a $100 \mathrm{~m}$ transect. In 2011, the sites were selected in areas of high densities of flowers known to be visited by bumble bees. We repeated the same procedure one year later at the same sites. At the sites where flower availability changed substantially from year to year, the second year we chose sites as close and similar as possible to those sites surveyed in 2011 (more details on sampling in Morales et al. 2013). Surveys on raspberries and patches of wild flowers were performed during standard weather conditions for pollinator surveys, only during windless days or days with light wind (Winfree et al. 2007), in order to avoid the remobilization of deposited ash.

In late November-early December 2010 and 2012, during the austral spring time (i.e., 6-7 months before and $\sim 17-18$ months after the eruption, respectively), we measured the proportion of triggered flowers in 32 populations of scotch broom scattered along a gradient of ash layer thickness ranging from 0 to $15 \mathrm{~cm}$ (Fig. 1). Populations were separated at least $6 \mathrm{~km}$ from each other; therefore, each population can be considered as an independent replicate regarding its bee-visiting fauna. In each population, we randomly selected three branches of about $30 \mathrm{~cm}$ from five randomly selected individual plants. On each branch we counted the total number of flowers and the flowers that had been triggered, and estimated the proportion of triggered flowers.

\section{Data analyses.}

A regression approach was used to characterize the relationship between thickness of the ash layer deposited on the ground and the number of wild bees (i.e. native bee species and invasive $B$. terrestris) visiting raspberry flowers per observation interval, and total bee species richness (i.e., also including managed Apis mellifera) per field. To analyze the effect of ash thickness on number of wild bees we used Generalized Lineal Mixed Models (GLMM) given the nested structure of the sampling design, which includes several observations per field and non-normal residuals (Crawley 2007). Because response variables are counts, we assumed a Poisson error distribution with a $\log$-link function. In the regression models, we included number of raspberry flowers observed in each census as an offset (i.e. a fixed predictor) and field as a random effect (Hill \& Gelman 2007).

The number of bumble bees observed foraging on patches of wild flowers per 30 min walk was modeled as a function of the thickness of the ash layer, the sampling season (categorical factor with two levels: 2011 and 2012), and the interaction between them. This allowed us to rule out the possibility that the location of the sites across the ash gradient could mask any other preexisting gradient. We used GLM and assumed a Poisson error distribution as explained above (Crawley, 2007).

The proportion of triggered flowers of scotch broom was modeled as a function of the ash layer thickness, the sampling season (categorical factor with two levels: 2010 and 2012), and the interaction between them. We used GLMM and considered population as a random effect (Crawley 2007). Because the response variable is a proportion, we assumed a binomial error distribution, and a logitlink function (Crawley 2007).

Real landscape data are inherently characterized by a spatial structure (i.e., nearby locations are more likely to have similar values in any response variable by chance alone, beyond any explanatory factor). Therefore, we performed additional analyses to evaluate whether our regression models adequately accounted for the spatial autocorrelation in the data. Sites located closer to each other could potentially be more similar in many aspects than those that are further apart, beyond any effect of ash deposition on the response variables. Therefore, we expected to find no evidence of spatial autocorrelation in the residuals of our regression models if ash layer thickness fully explained the spatial structure of the data. To evaluate this possibility, we averaged the residuals of all individual observations per raspberry field and scotch broom population estimated from the hierarchical models for all the response variables and correlated two distance matrices, the matrix of geographic distances and the matrix of the absolute difference of the mean residual between all pairs of sampled sites. We then estimated the Mantel correlation coefficient and estimated its significance based on 10000 random permutations of one of the matrices (Legendre \& Fortin 1989). This approach was not applied to bumble bee data because the sample size was too small.

In all analyses we transformed the variable ash layer thickness (in cm), as $\ln (x+1)$, because the value of the predictor variable for many observations had 0 $\mathrm{cm}$ of ash. All analyses were run on the free software $R$ versión 2.13.1(R Development Core Team, 2005).

\section{Results}

\section{Raspberry}

We observed a total of 1802 bee-pollinators belonging to nine bee taxa visiting raspberry flowers. Overall, the managed honey bee, $A$. 
mellifera, was the most abundant bee species, accounting for $50 \%$ of total bee abundance, while the invasive $B$. terrestris was the most abundant among wild bees, accounting for $40 \%$ of total bee abundance. Native bees accounted for the remaining 10\%. Among these, Cadeguala albopilosa (Colletidae) and Ruizantheda mutabilis (Halictidae) were by far the most frequently observed; other bee taxa could only be identified as morphospecies. During the flowering season after the eruption, the number of $B$. terrestris and native bees visiting raspberry flowers decreased with increasing ash layer thickness (estimate \pm SE $=-1.69 \pm 0.21, Z=-7.85, P<0.001$ and $-1.98 \pm$ $0.71, Z=-2.77, P=0.005$, respectively), by 97 and $100 \%$ from fields without ash to fields with approximately $10 \mathrm{~cm}$ of deposited ash, respectively (Figure 2a). Furthermore, total bee species richness per field significantly decreased with increasing thickness of the ash layer (estimated $\pm \mathrm{SE}=-0.57 \pm 0.21, \mathrm{Z}=-2.64, P$ $=0.008$ ). Fields without ash had, on average, $\sim 5$ different bee taxa visiting raspberry flowers, while fields with a layer of $10 \mathrm{~cm}$ had only $\sim 1$ taxon (Figure 2b). Bombus terrestris was the only wild bee present in all fields across the ash gradient. Mantel tests provided no evidence of spatial autocorrelation on the residuals of the number of $B$. terrestris $(P=0.79)$ or of native bees $(P=0.33)$ visiting raspberry flowers, or total bee richness per field $(P=0.8681)$. Accordingly, the spatial structure of the data did not explain any significant variation in visitation beyond that explained by varying ash deposition.

\section{Bumble bees}

The invasive $B$. terrestris was the most widespread bumble bee species and the most frequently observed foraging on patches of wild flowers, accounting for 88 and $96 \%$ of all Bombus individuals recorded during the summer before (2011) and after (2012) the eruption respectively, and being present in ten and eight out of ten sites before and after the eruption, respectively. The second invasive species, B. ruderatus, accounted for $\sim 11 \%$ and $\sim 3 \%$ of total bumble bee abundance, and was recorded in three and one site before and after the eruption, respectively. In contrast, the native $B$. dahlbomii accounted for $<1 \%$ of all observed bumble bees and was recorded in a single site in each season. We found a highly significant drop in the mean number of bumble bees observed visiting wild flowers in general $(Z=-6.976, P<0.001)$, and of $B$. terrestris in particular $(\mathrm{Z}=-6.072, P<0.001)$ between the sampling seasons before and after the eruption. Changes in the number of individuals of the remaining species were not evaluated because of zero values at most of the sites. After the eruption, the total number of bumble bees per site was on average less than half as numerous as before the eruption
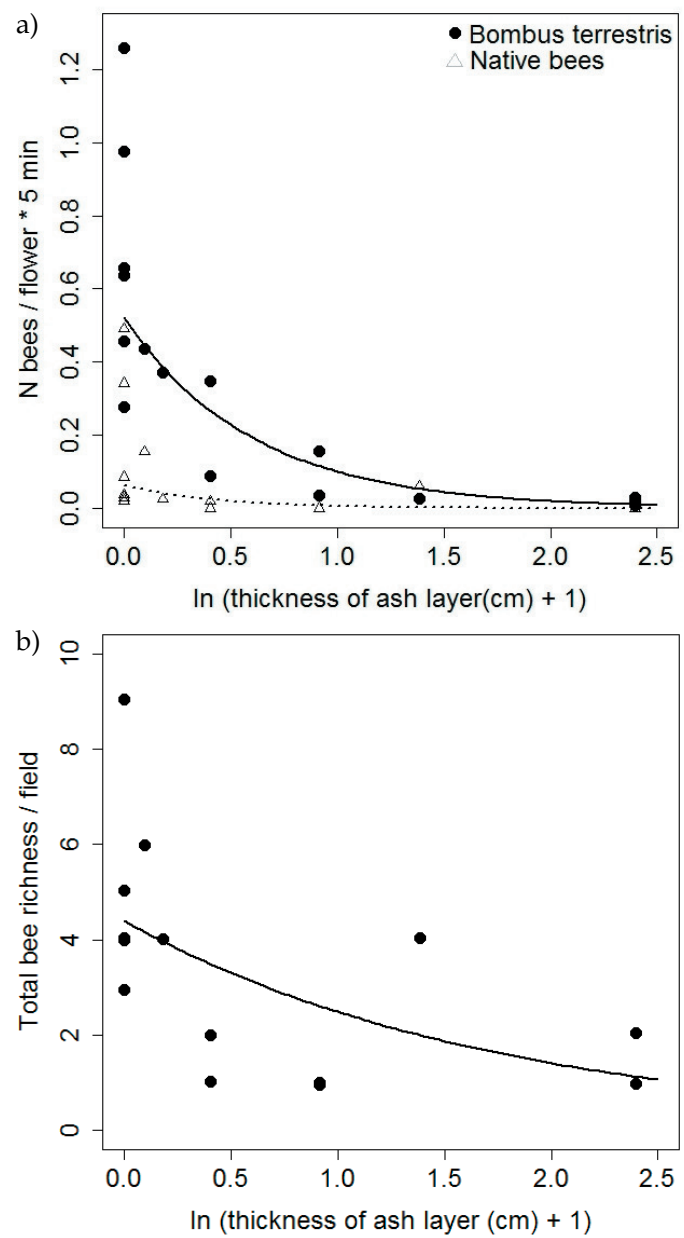

Figure 2. (a) Relation between the number of Bombus terrestris (black circles) and native bee (white triangles) individuals visiting raspberry flowers per five minute observation intervals and ash layer thickness. Solid and dashed lines indicate the fitted curves for $B$. terrestris and native bees, respectively, estimated from the Poisson model. (b) Relation between total bee richness per field and ash layer thickness. The solid line indicates the fitted curve estimated from the Poisson model.

Figura 2. (a) Relación entre el número de individuos de Bombus terrestris (círculos negros) y de abejas nativas (triángulos blancos) que visitan las flores de frambuesa por intervalo de observación de cinco minutos y el espesor de la capa de cenizas. Las líneas solidas y punteadas indican las curvas ajustadas para B. terrestris y abejas nativas, respectivamente, estimadas del modelo de Poisson. (b) Relación entre la riqueza total de abejas por campo y el espesor de la capa de cenizas. La línea sólida indica la curva ajustada estimada del modelo de Poisson. 
(mean number of bumble bees per transect \pm SD: year $2011=23.2 \pm 13.2$, year $2012=10.1$ \pm 12.2 ). In particular, this trend was driven by the overall most numerous species, $B$. terrestris, which dropped from $20.5 \pm 14.6$ to $9.7 \pm 12.2$ individuals per transect. Moreover, the site with the thickest ash layer $(5 \mathrm{~cm})$ was completely devoid of bumble bees.

The interaction between the effect of sampling season (2011 and 2012, before and after the eruption, respectively) and ash layer thickness was highly significant (interaction $\pm \mathrm{SE}=$ $-0.6673 \pm 0.2175, Z=-3.068, P=0.002$, Figure 3). We found a negative and highly significant effect of the (ln-transformed) thickness of the ash layer on the number of bumble bees recorded after the eruption (estimate $\pm \mathrm{SE}=$ $-0.78238 \pm 0.1900, P<0.0001)$. Conversely, we did not observe this effect on the number of bumble bees recorded before the eruption ($0.1165 \pm 0.1059, P=0.271$, Figure 3 ).

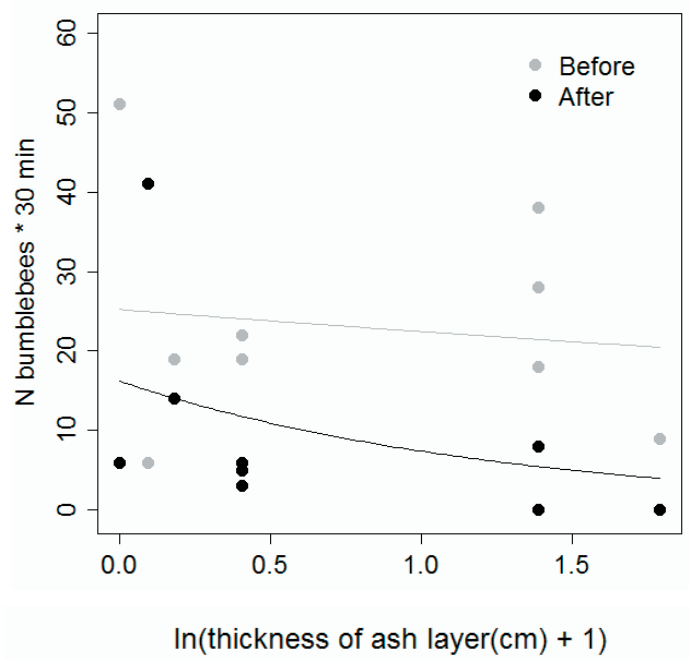

Figure 3. Relation between the number of bumble bees observed foraging on patches of wild flowers per site during $30 \mathrm{~min}$-walks along $100 \mathrm{~m}$-transect in the summer before (2011, in grey) and after (2012, in black) the eruption of PCC volcanic complex, and ash layer thickness (cm).

Figura 3. Relación entre el número de abejorros observados forrajeando en parches de flores silvestres por sitio durante caminatas de $30 \mathrm{~min}$. a lo largo de transectas de $100 \mathrm{~m}$. en el verano anterior (2011, en gris) y posterior (2012, en negro) a la erupción del complejo volcánico PCC, y el espesor de la capa de ceniza $(\mathrm{cm})$.

\section{Scotch Broom}

The proportion of triggered flowers was significantly higher before (2010) than after (2012) the eruption $(Z=10.05 ; P<0.001)$. On average, the proportion of triggered flowers per population after the eruption was $7 \%$ lower than before (mean proportion \pm SD: $2010=$ $0.51 \pm 0.16,2012=0.45 \pm 0.16)$. The interaction between the effect of sampling season and ash layer thickness was highly significant (interaction $\pm \mathrm{SE}=0.241 \pm 0.014, \mathrm{Z}=11.24$; $P<0.001$; Figure 4). We found a significant and negative effect of the (ln-transformed) ash layer thickness on the proportion of triggered flowers after the eruption (estimate $\pm \mathrm{SE}=-0.495 \pm 0.167, Z=-2.95 ; P=0.003)$, but not before it (estimate $\pm S E=-0.294 \pm 0.303$, $Z=-0.971 ; P=0.332)$. Mantel tests provided no evidence of spatial autocorrelation on the residuals of the proportion of triggered flowers after the eruption $(P=0.44)$. Accordingly, the spatial structure of the data did not explain any significant variation in visitation beyond that explained by ash deposition.

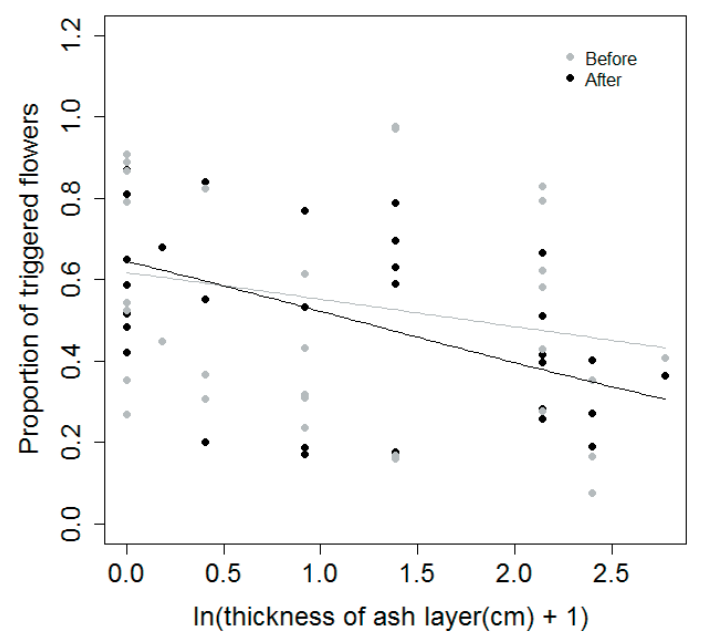

Figure 4. Relation between the proportion of triggered flowers of Scotch Broom per population the spring before (December 2010, in grey) and after (December 2012, in black) the eruption of PCC volcanic complex, and ash layer thickness $(\mathrm{cm})$.

Figura 4. Relación entre la proporción de flores de retama gatilladas por población la primavera anterior (Diciembre 2010, en gris) y posterior (Diciembre 2012, en negro) a la erupción del complejo volcánico PCC, y el espesor de la capa de cenizas $(\mathrm{cm})$.

\section{DisCUSSION}

The 2011 volcanic eruption of the PCC strongly disrupted bee fauna and plantpollinator interactions (PPI) during the two flowering seasons following the eruption, as exemplified by consistent results among the three case studies. Specifically, we found that the abundance of bumble bees foraging in patches of wild flowers and the proportion of triggered flowers of scotch broom decreased with ash level thickness, and overall in comparison to pre-eruption levels. These 
effects extended $>100 \mathrm{~km}$ from the eruption epicenter, suggesting that the influence of the volcanic event on plant-pollinator interactions was experienced on a regional scale.

The observed detrimental effect on bees and PPI of ash deposited on the ground may result from decreased survival of bees, altered behavior or both. Our study does not allow us to separate these two non-mutually exclusive effects, and both mechanisms are probably involved in the observed patterns. However, we argue that our results reflect an overall reduction in the bee populations more closely than an altered behavior induced by ash, leading to a reduction in the flower visitation activity of bees.

The overall reduction in the number of bees foraging on either cultivated or wild plant species is consistent with the reported evidence of lethal and sublethal effects of ash particles in general, and of those released by the PCC eruption in particular on many insect taxa, including bees (Buteler et al. 2011; Fernandez-Arhex et al. 2013; Martínez et al. 2012). More importantly, the volcanic eruption occurred few days before the start of the austral winter, so ash deposition could have buried many individuals of bee species that remain inactive underground during the winter. Furthermore, in colonial species such as bumble bees only the new fertilized queens survive after the flowering season, hibernating underground until the following spring (Heinrich 1979). Therefore, the fall of a thick layer of ash during winter may have impeded the spring emergence of the hibernating queens, thus precluding the foundation of new colonies. Finally, ash deposition is also expected to alter the short-term availability of floral resources, in particular if ash fall killed some plants or buried small herbaceous or cushion plants, which in turn may also affect bee survival and reproduction.

Regarding behavioral changes, although a recent study confirms that flowers covered with PCC ash were less attractive and therefore less visited by honey bees (Martínez et al. 2012), this effect seems to be a short term response that was partly overcome a few hours after ash fall. Our sampling was carried out in the temperate forests in the western sector of the overall area affected by ash deposition, where the precipitations are comparatively higher and the size of ash particles larger than in the dry steppe of the eastern sector
(Gaitán et al. 2011b). This landscape context, together with the fact that surveys were done during days without wind and seven or eighteen months after the major eruption event, suggest that ash (in the air or in the flowers) had negligible effects on bee behavior. Arguably, changes in behavior associated with foraging could possibly impair reproduction or survival. Therefore, the decrease in bee numbers observed during the summer following the major eruption (JanuaryFebruary 2012), as well as in the subsequent late spring (November-December 2012) may partially reflect population reduction resulting indirectly from behavioral changes experienced earlier in the flowering season or in the previous season, respectively.

Our results show that the detrimental effect of volcanic ash on PPI persisted for at least two seasons after the major volcanic eruption, as shown by the decrease in the proportion of triggered flowers of scotch broom. However, the magnitude of the effect detected in scotch broom during the second flowering season after the eruption seems to be relatively low compared to effects on total bee richness and number of wild bees visiting raspberry flowers, as well as on the number of bumble bees visiting wild flowers in the first flowering season after the eruption. This difference may be not only due to the effect of ash deposition diluted with time as it is gradually compacted by rainfall and vegetation regrowth (Gaitán et al. 2011b), together with a partial recovery of wild bee populations, and $B$. terrestris in particular, but could also be due to differences in methodology and response variables.

The strong reduction in number and richness of bees visiting flowers as a result of this volcanic event might have multiple cascading impacts on: (1) the delivery of the pollination service to crops, (2) the invasion success of introduced bumble bees and the interactions with native bumble bee species and, (3) the spreading success of a pollinator-dependent invasive plant. We found that the thickness of the ash layer deposited on the ground strongly reduced the number and richness of pollinating bees in raspberry fields, which could eventually impair the pollination service to this crop. However, Saez et al. (submitted) found no evidence of pollination limitation in terms of number of drupelets and fruit weight along this gradient of decreasing bee abundance with increasing ash deposition, with adequate pollination levels even at the 
highest levels of ash deposition. The fact that $B$. terrestris was the only persisting species may not reflect only its high resistance to strong environmental disturbances, but also its previous extremely high abundance, such that the negative impact of ash deposition was not enough to reduce its populations below a threshold that can affect raspberry pollination. In any case, in the flowering season subsequent to the eruption, the number of $B$. terrestris visiting raspberry flowers was more than enough to ensure pollination quantity in raspberry fields. However, as the productivity of some crops is benefited by pollinator diversity, regardless of abundance (Klein et al. 2003), this example illustrates how a large-scale disturbance can eventually compromise the short-term release of a key ecosystem service, such as crop pollination.

We found a significant reduction in the number of bumble bees, in particular of $B$. terrestris, recorded in transects with increasing ash deposition. This is remarkable, given the low sample size and the high variability among sites in the composition of the flowering plant community and the availability of flowers. The effect of ash deposition could not be evaluated on other bumble bee species because their abundances were already low before the eruption due to their displacement by B. terrestris (Morales et al. 2013). On the one hand, if the effects of ash on $B$. terrestris last for several seasons, it might open a window of opportunity for populations of native $B$. dahlbomii to recover from the competitive pressure of this invasive congener. On the other hand, our results show that even a large scale natural disturbance like a volcanic eruption cannot counteract the long lasting and large scale impact driven by an introduced invasive species such as $B$. terrestris.

A volcanic event can indirectly affect the reproductive success of a pollinator dependent plant species, such as scotch broom, through its effect on bee populations. Related to these indirect effects, Goulson (2005) hypothesized that a positive feedback between invader pollinators, in particular B. terrestris, and seed production of $C$. scoparius, would increase its invasive potential through increased fitness. Thus, a decrease in the abundance of this invasive bumble bee is expected to reduce the reproductive success of scotch broom because of its strong dependence on large bees for pollination (Parker 1997). The observed decrease in the proportion of triggered (i.e., visited) flowers with increasing ash deposition strongly supports this expectation (Figure 4). Consequently, an extraordinary natural event like a volcanic eruption and subsequent ash deposition could be considered as a timelimited opportunity to reinforce control efforts on a vigorous invader such as C. scoparius.

In conclusion, the ash deposited from the PCC eruption impacted negatively on the bee pollinator fauna, which may affect different stages of reproduction of some flowering plant species, such as flower fertilization and fruit formation in scotch broom and raspberry (Saez et al. submitted), respectively. However, our results show that although bee fauna was severely affected, B. terrestris persisted, even in the sites with high levels of ash deposition. It remains unclear whether the survival of $B$. terrestris derives from the species resistance to ash, or from the simple fact that its general overabundance (Morales et al. 2013; Saez et al. submitted) increases the probability of population persistence. Future surveys are necessary to assess whether the effects reported here persist in the longer term.

\begin{abstract}
Acknowledegments: We thank A. Ruggiero for inviting us to join this special issue, and for her patience. This study was funded by: Rufford Small Grants for Conservation; Agencia de Ciencia y Tecnica via PICTs: 2007-01464, 2007-01300 and 2012-3015 (Préstamo-BID, all three projects), the PIP-112-200801-01623- Préstamo BID and Universidad de Río Negro PI 40-B-259. We thank National Park Administration and the raspberry farm owners for fieldwork permits, A. Novarro for logistic help and A. Montero, L. Ramos, B. Eckert and D. Lopez for field assistance. CLM and MAA are researchers at the National Research Council of Argentina (CONICET), AS and LC hold scholarships from the same institution and MPA is a researcher from Universidad Nacional de Río Negro. We thank T. Kitzberger and two anonymous reviewers for their constructive comments on an early version of this article.
\end{abstract}

\section{REFERENCES}

Aizen, MA; DP VÁzQUEZ \& C SMith-RAmírez. 2002. Historia natural y conservación de los mutualismos plantaanimal del bosque templado de Sudamérica austral. Rev. Chil. Hist. Nat., 75:79-97.

Buteler, M; T Stadler; GP López García; MS Lassa; D Trombotto Liaudat; P D'Adamo \& V Fernandez-Arhex. 2011. Propiedades insecticidas de la ceniza del complejo volcánico Puyehue-Cordón Caulle y su posible impacto ambiental. Rev. Soc. Entomol. Argent., 70:149-156.

CAldwell, BA. 2006. Effects of invasive scotch broom on soil properties in a Pacific coastal prairie soil. Appl. Soil Ecol., 32:149-152.

CANE, JH. 2005. Pollination potential of the bee Osmia aglaia for cultivated red raspberries and blackberries (Rubus: Rosaceae). HortScience, 40:1705-1708.

Crane, E \& P WALKER. 1984. Pollination directory for world 
crops. International Bee Research Association.

Crawley, MJ. 2007. The R book. Wiley. 942pp.

GAITÁn, JJ; JA Ayesa; F UMAÑa; F RAFFo \& DB BRAn. 2011a. Cartografía del área afectada por cenizas volcánicas en las provincias de Río Negro y Neuquén. Available in: http://triatlon.bariloche2000.com/digidoc/Mapa_ cenizas.pdf

Gaitán, JJ; JA Ayesa; F RafFo; F Umaña; DB Bran \& H MoraGa. 2011b. Monitoreo de la distribución de cenizas volcánicas en Río Negro y Neuquén: situación a los 6 meses de la erupción. Laboratorio de Teledetección - SIG, INTA EEA Bariloche.

Gathmann, A \& T TscharntKe. 2002. Foraging ranges of solitary bees. J. Anim. Ecol.,71: 757-764.

FernandeZ-ArheX, V; M Buteler; ME AMAdio; A EnRIQueZ; Al Pietrantuono; T Stadler; G Becker \& O Bruzzone. 2013. The effects of volcanic ash from Puyehue.Caulle range eruption on the survival of Dichroplus vittigerum (Orthoptera: Acrididae). Florida Entomol., 96:286-288.

Goes. 2011. Available on: http://goes.gsfc.nasa.gov/ text/goes13results.html\#110604-06_volcano_chile.mov (downloaded on June/2013).

Goulson, D. 2005. Risks of increased weed problems associated with introduction of non-native bee species. J. Food, Agric. Environ., 3: 11-13.

GREENLEAF, SS; NM Williams; R Winfree \& C KREMEN. 2007. Bee foraging ranges and their relationship to body size. Oecologia, 153: 589-596.

Gullan, PJ \& PS CRanston. 2005. The Insects. An Outline of Entomology. Blackwell, Malden.

Hill, J \& A Gelman. 2007. Data Analysis Using Regression and Multilevel/Hierarchical Models. Cambridge University Press.

Heinrich, B. 1979. Bumblebee Economics. Harvard University Press, Cambridge.

Klein, AM; I StefFan-Dewenter \& T TscharntKe. 2003. Fruit set of highland coffee increases with the diversity of pollinating bees. Proc. R. Soc. B., 270:955-961.

Klein, AM; BE Vaissiere; JH Cane; I Steffan-Dewenter; SA Cunningham; C Kremen \& T TscharntKe. 2007. Importance of pollinators in changing landscapes for world crops. Proc. R. Soc. B., 274:303-313.

Klein, AM; I Steffan-Dewenter \& T TscharntKe. 2004. Foraging trip duration and density of megachilid bees, eumenid wasps and pompilid wasps in tropical agroforestry systems. J. Anim. Ecol., 73:517-525.

Klostermeyer, EC; LD Corpus \& CL Campbell.1981. Population changes in arthropods in wheat following volcanic ash fallout. Melanderia, 37:45-49.

Legendre P \& MJE Fortin. 1989. Spatial pattern and ecological analysis. Vegetatio, 80: 107-138.

MarsKe, KA; MA Ivie \& GF HiLton. 2007. Effects of volcanic ash on the forest canopy insects of Monserrat, West Indies. Environ. Entomol., 36: 817-825.

Martínez, AS; M Masciocchi; JM Villacide; G Huerta; L Daneri; A BruchHausen; G Rozas \& JC Corley. 2012. Ashes in the air: the effects of volcanic ash emissions on plant-pollinator relationships and possible consequences for apiculture. Apidologie, 1-10.

Mogni, L; C Cotaro \& R Daga. 2011. Análisis preliminar cenizas volcánicas sistema Puyehue- Cordón Caulle - 04-06-11. Available on: http://www.cnea.gov.ar/ pdfs/noticias/2011/InformePreliminarCenizasPuyeh
ueCAB.pdf. (Downloaded on June/2013)]

MorALES, CL. 2009. Pollination Requirement of Raspberry in SW Argentina. Preliminary Results. Int. J. Plant Rep. Biol., 1:195-198.

Morales, CL; MP Arbetman; SA Cameron \& MA Aizen. 2013. Rapid ecological replacement of a native bumble bee by invasive species. Front. Ecol. Environ.11, 529534.

PARKER, IM. 1997. Pollinator limitation of Cytisus scoparius (Scotch broom), an invasive exotic shrub. Ecology, 78: 1457-1470.

Pérez, A. 2008. Reserva de la Biosfera Andino Norpatagonica. In: Schüttler, E \& CS Karez (eds) Especies exóticas invasoras en las Reservas de Biosfera de América Latina y el Caribe. Un informe técnico para fomentar el intercambio de experiencias entre las Reservas de Biosfera y promover el manejo efectivo de las invasiones biológicas. UNESCO, Montevideo.

Potter, KJB; DJ Kriticos; MS Watt \& A Leriche. 2009. The current and future potential distribution of Cytisus scoparius: a weed of pastoral systems, natural ecosystems and plantation forestry. Weed Res, 49:271-282.

R Development Core Team. 2005. R: A language and Environment for Statistical Computing. R Foundation for Statistical Computing, Vienna, Austria.

Roig-Alsina, A \& MA Aizen. 1996. Bombus ruderatus Fabricius, un nuevo Bombus para la Argentina (Hymenoptera: Apidea). Physis, 5:49-50.

SAEZ, A; CM Morales; L RAMOS \& MA Aizen. Intensive bee visitation decreases fruit quality by damaging flower styles despite increasing pollen deposition in raspberry. J. Appl. Ecol. submitted.

Singer, BS; BR Jicha; MA Harper; JA Naranjo; LE Lara \& H MORENO-ROA. 2008. Eruptive history, geochronology, and magmatic evolution of the Puyehue-Cordón Caulle volcanic complex, Chile. Geol. Soc. Am. Bull., 120:599-618.

SCHOWALTER, TD 2012. Insect responses to major landscapelevel disturbance. Annual Review of Entomology, 57:1-20.

Steffan-Dewenter, I \& A Kunn. 2003. Honey bee foraging in differentially structured landscapes. Proc. R. Soc. B., 270:569-575.

Torretta, JP; D Medan \& AH Abrahamovich. 2006. First record of the invasive bumble bee Bombus terrestris (L.) (Hymenoptera, Apidae) in Argentina. Trans. Am. Ent. Soc., 132:285-289.

VÁzQUeZ, DP \& D SimberLoff. 2003. Changes in interaction biodiversity induced by an introduced ungulate. Ecol. Lett., 6:1077-1083.

Winfree, R; NM Williams; J DushoffF \& C KREMEN. 2007. Native bees provide insurance against ongoing honey bee losses. Ecol. Lett., 10:1105-1113.

Wille, A \& G FuENTES. 1975. Efecto de la ceniza del Volcán Irazú (Costa Rica) en algunos insectos. Rev. Biol. Trop., 23:165-175.

WILSON, TM;JW COLE; CSTEWART; SJ CRONIN \& DMJOHNSTON. 2010. Ash storms: impacts of wind-remobilized volcanic ash on rural communities and agriculture following the 1991 Hudson eruption, southern Patagonia, Chile. Bull. Volcanol., 73:223-239.

WOYKe, J \& J GABKA. 2011. Effect of volcanic ash cloud over Poland on flight activity of honey bees. J. Apic. Sci., 55:5-17. 